Louisiana State University

LSU Digital Commons

Faculty Publications

Department of Geology and Geophysics

$4-1-2018$

\title{
The Sabine block, Gulf of Mexico: Promontory on the North American margin?
}

\author{
Peter D. Clift \\ Louisiana State University \\ Paul Heinrich \\ Louisiana Geological Survey \\ Dennis Dunn \\ The University of Texas at Austin \\ Andrew Jacobus \\ Binghamton University State University of New York \\ Jerzy Blusztajn \\ Woods Hole Oceanographic Institution
}

Follow this and additional works at: https://digitalcommons.Isu.edu/geo_pubs

\section{Recommended Citation \\ Clift, P., Heinrich, P., Dunn, D., Jacobus, A., \& Blusztajn, J. (2018). The Sabine block, Gulf of Mexico: Promontory on the North American margin?. Geology, 46 (4), e441-e441. https://doi.org/10.1130/ G40162Y.1}

This Letter to the Editor is brought to you for free and open access by the Department of Geology and Geophysics at LSU Digital Commons. It has been accepted for inclusion in Faculty Publications by an authorized administrator of LSU Digital Commons. For more information, please contact ir@lsu.edu. 


\section{The Sabine block, Gulf of Mexico: Promontory on the North American margin?}

\section{Peter D. Clift ${ }^{1}$, Paul Heinrich ${ }^{2}$, Dennis Dunn ${ }^{3}$, Andrew Jacobus ${ }^{4}$, and Jerzy Blusztajn ${ }^{5}$}

${ }^{1}$ Department of Geology and Geophysics, E235 Howe-Russell, Louisiana State University, Baton Rouge, Louisiana 70803, USA

${ }^{2}$ Louisiana Geological Survey, Louisiana State University, 3079 Energy, Coast and Environment Building, Baton Rouge, Louisiana 70803, USA

${ }^{3}$ College of Natural Science, University of Texas at Austin, Austin, Texas 78712, USA

${ }^{4}$ Department of Geological Science and Environmental Studies, Binghamton University, Binghamton, NY

${ }^{5}$ Department of Geology and Geophysics, Woods Hole Oceanographic Institution, Woods Hole, Massachusetts 02540, USA

We thank Van Avendonk and Dalziel (2018) for their comment on our paper (Clift et al., 2018) concerning the U-Pb ages of zircon crystals from granite xenoliths within the Prairie Creek Lamproite of southwest Arkansas, United States. They emphasize the role that seismic data can play in understanding the tectonics of the Ouachita Foldbelt, and favor a model in which this belt was formed as a result the collision of Laurentia with exotic terrains in the early Paleozoic (Keller et al., 1989). It is clear that the crust of the Sabine Block is substantially thinner than that found further inboard, $\sim 30 \mathrm{~km}$ compared to $\sim 40 \mathrm{~km}$, and that the Ouachitas therefore represent an important tectonic boundary. The U-Pb ages of the granitic zircons leave open the possibility that the Sabine Block is exotic to Laurentia, but if so, then the accretion appears to have been older than implied by the seismic data alone. K-Ar dates of 1.34-1.48 Ga from amphibolite xenoliths found in the same pipes indicate that at least some of the crust under the area is associated with the Granite Rhyolite Belt (GRB), and that the Sabine Block was therefore part of Laurentia when the GRB was active (Dunn, 2009). This is despite the fact that few zircon grains of GRB age have been found by this more recent study. The Prairie Creek Pipes appear to lie just to the south of the Alabama-Oklahoma transform boundary of Thomas (2011) so that granites in the pipes need not closely correlate with rocks dated from north of that structure. There is clearly no simple correlation between the new granite ages and either
Grenville or GRB ages. This implies either that the magmatism associated with these orogenic events was not ubiquitous across the region, or that the Sabine Block is exotic to Laurentia. While the U-Pb zircon ages alone would be compatible with the Paleozoic accretion of Laurentian or Gondwanan magmatic arcs to the southern edge of Laurentia, as suggested by Van Avendonk and Dalziel, such a model is at odds with the pre-GRB accretion implied by the amphibolite K-Ar ages of Dunn (2009). We do not rule out an earlier exotic origin and accretion, but prefer the idea of the Sabine Block being an extension of Laurentia as being the simplest solution to the current data set. The seismic data and the amphibolite xenolith K-Ar ages appear to be at odds with one another in terms of the tectonic origin of the Sabine Block. An accretion of the Sabine Block as an exotic terrane during the Paleozoic would only be favored if the K-Ar ages were not considered robust.

\section{REFERENCES CITED}

Clift, P.D., Heinrich, P., Dunn, D., Jacobus, A., and Blusztajn, J., 2018, The Sabine block, Gulf of Mexico: Promontory on the North American margin?: Geology, v. 46, p. 15-18, https://doi.org/10.1130/G39592.1.

Dunn, D.P., 2009, Arkansas crustal xenoliths: Implications for basement rocks of the northern Gulf Coast, USA: Lithosphere, v. 1, p. 60-64, https://doi.org/10.1130/L10.1.

Keller, G.R., Braile, L.W., McMechan, G.A., Thomas, W.A., Harder, S.H., Chang, W.-F., and Jardine, W.G., 1989, Paleozoic continent-ocean transition in the Ouachita Mountains imaged from PASSCAL wide-angle seismic reflection refraction data: Geology, v. 17, p. 119-122, https://doi.org /10.1130/0091-7613(1989)017<0119:PCOTIT>2.3.CO;2.

Thomas, W.A., 2011, The Iapetan rifted margin of southern Laurentia: Geosphere, v. 7, p. 97-120, https://doi.org/10.1130/GES00574.1.

Van Avendonk, H.J.A., and Dalziel, I.W.D., 2018, The Sabine block, Gulf of Mexico: Promontory on the North American margin?: Comment: Geology, v. $46,10.1130 / \mathrm{G} 40053 \mathrm{C} .1$ 